\title{
ГЕОХИМИЯ ЭЛЕМЕНТОВ ПЛАТИНОВОЙ ГРУППЫ В БАЗАЛЬНОМ \\ ПЛАТИНОМЕТАЛЬНО-МЕДНО-НИКЕЛЕВОМ ОРУДЕНЕНИИ МАССИВА НЮД, МОНЧЕГОРСКИЙ КОМПЛЕКС
}

\author{
Припачкин П.В. ${ }^{1}$, Грошев Н.Ю. ${ }^{1}$, Кариковски Б.Т. ${ }^{2}$, Майер В.Д. ${ }^{2}$, Макдональд Я. ${ }^{2}$, \\ Барнс С.-Дж. ${ }^{3}$, Савард Д. ${ }^{3}$ \\ ${ }^{1}$ Геологический институт КНЦ РАН, Anamumbl, paul@geoksc.apatity.ru \\ ${ }^{2}$ Школа наук о Земле и Океане, Кардифф \\ ${ }^{3}$ Университет Квебека в Чикутими, Чикутими
}

\section{Введение}

Тонкая геохимия цветных и благородных металлов сегодня является эффективной методикой, позволяющей глубже понять и смоделировать генезис рудной минерализации расслоенных интрузий. Особенности поведения этих металлов в ходе магматических процессов и экспериментальные данные о том, какие минеральные фазы ответственны за их концентрацию, были детально рассмотрены [2] на примере российских Норильск-Талнахских медно-никелевых месторождений и платинометальных рифов Меренского и UG-2 в комплексе Бушвельд (ЮАР). В настоящем исследовании нами впервые для Мончегорского расслоенного комплекса был применен подобный подход с целью моделирования условий образования так называемой донной (базальной) рудной залежи массива Нюд, вскрытой скважиной номер 1815 (рис. 1).

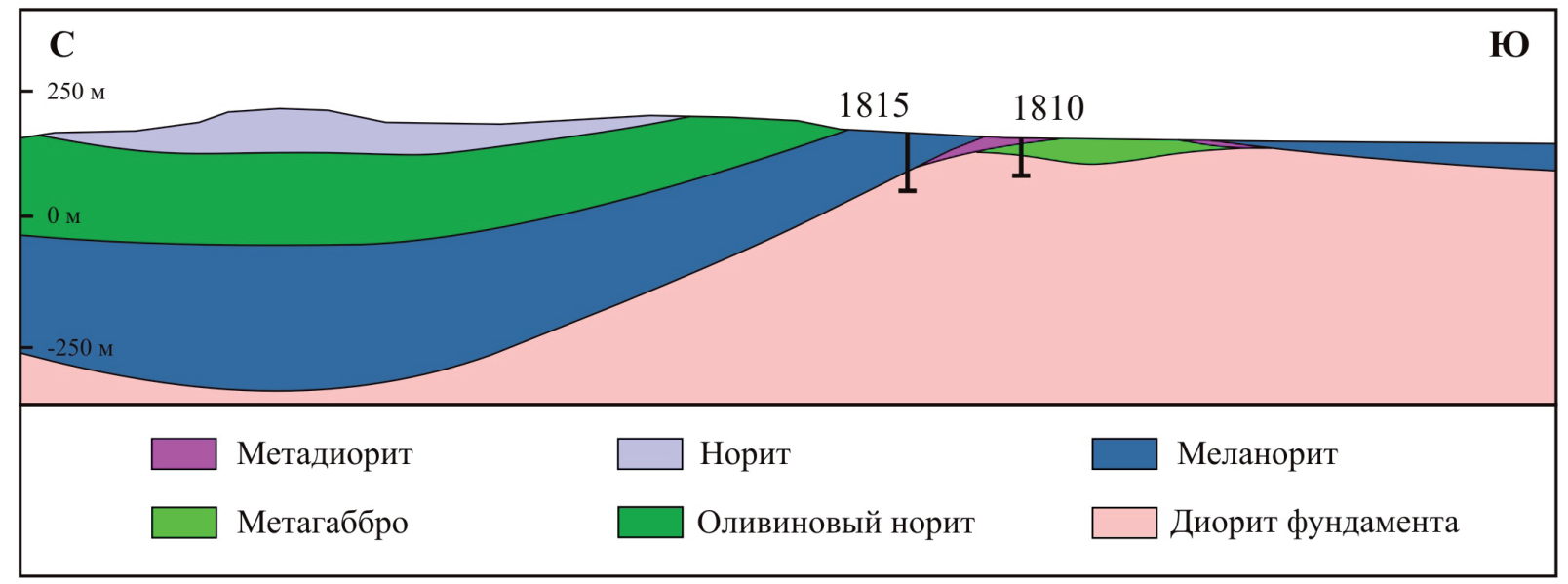

Рис. 1. Схематический геологический разрез массивов Нюд, Габбро 10-й аномалии и Верхний Нюд с расположением буровых скважин.

\section{Материалы и методы исследований}

После дробления и истирания в агатовой планетарной мельнице образцы по скважине 1815 были проанализированы на $\mathrm{Cu}, \mathrm{Ni}, \mathrm{Au}$ и шесть ЭПГ в университете Квебека в Чикутими (УКВЧ) методом ICP-MS после никель-серной пробирной плавки по аналитическому протоколу, изложенному в работе [7]. Сера анализировалась с использованием высокотемпературного горения с IR-спектрометрическим окончанием и титрованием серы на приборе Horiba 220V S-C в УКВЧ.

\section{Результаты исследований и обсуждение}

В разрезе скважины (рис. 2) пересечены среднезернистые и мелкозернистые меланориты, представляющие расслоенную серию и эндоконтакт массива Нюд соответственно. Ниже базального контакта, в кварцевых диоритах архейского фундамента развиты многочисленные жилы кварцполевошпатовых пегматитов. Видимая сульфидная халькопирит-пентландит-пирротиновая вкрапленность отмечается в мелкозернистых меланоритах и ее объем увеличивается в направлении контакта. Кроме этого, архейские диориты также содержат вкрапленные сульфиды. 


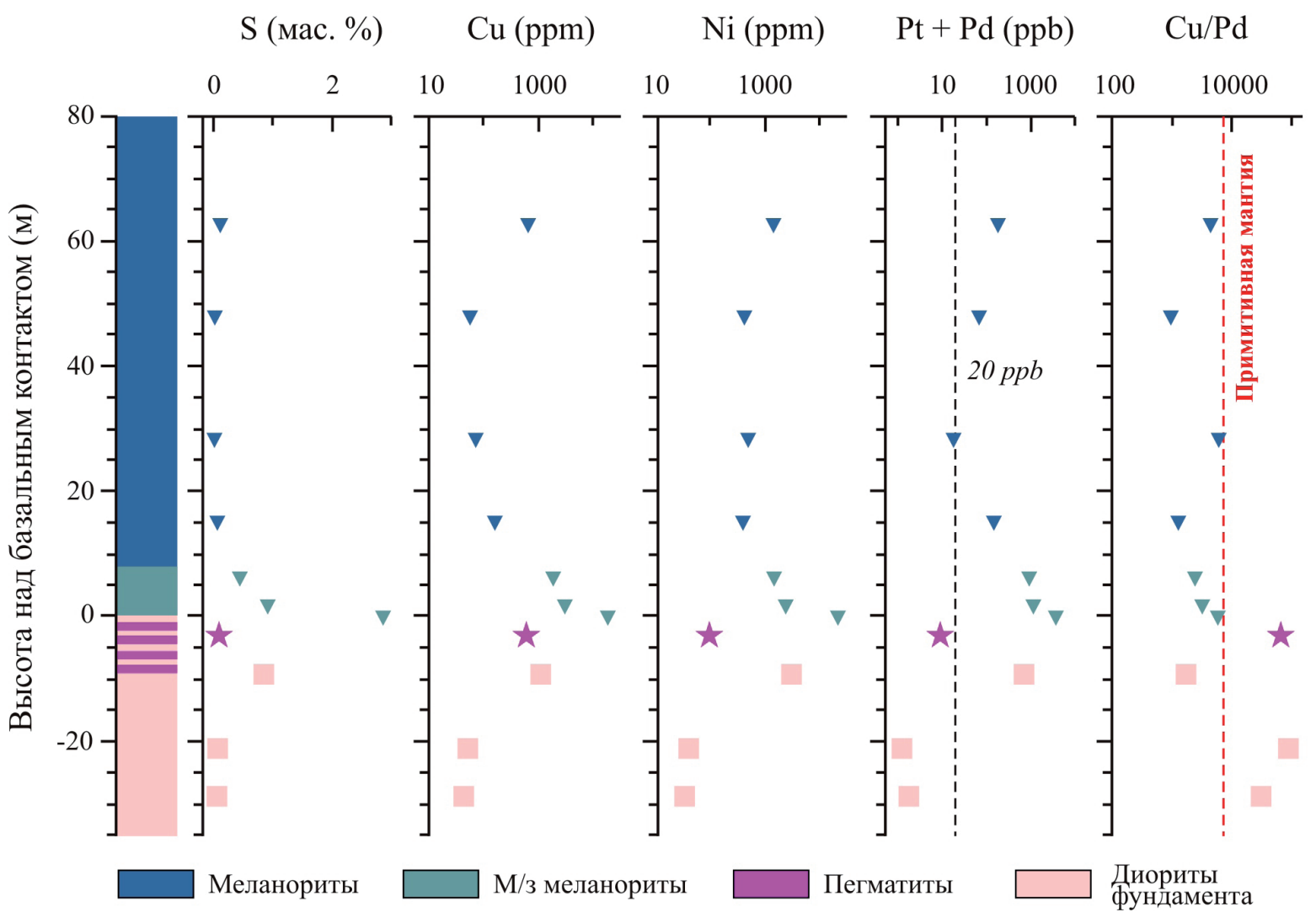

Рис. 2. Вариации концентраций халькофильных элементов по разрезу оазального оруденелого контакта массива Нюд.

Концентрация $\mathrm{Pt}+\mathrm{Pd}$ в пробах меланоритов превышает мантийные значения (рис. 2). Это, наряду с низким отношением $\mathrm{Cu} / \mathrm{Pd}$, свидетельствует о присутствии кумулусных сульфидов во всем разрезе. Насыщенность пород серой по разрезу массива Нюд, а также практически идентичные спектры халькофильных элементов, нормированных к примитивной мантии (рис. 3), требуют раннего насыщения серой, которое, наиболее вероятно, произошло в промежуточной камере на глубине. Поскольку растворимость серы в магме частично контролируется активностью кремнезема, ассимиляция породами фундамента могла привести к серному насыщению, как предполагается для многих магматических месторождений сульфидов [6]. Дополнительные свидетельства приводятся в работе [3], где на основе анализа нескольких изотопов серы предполагается, что насыщение серой в Мончегорском комплексе произошло скорее в результате ассимиляции магмы породами фундамента, нежели в ответ на добавление внешней серы в систему.

В момент внедрения ассимилированной магмы, содержащей обогащенные ЭПГ сульфидные капли вместе с прото-кумулусными силикатными минералами, породы фундамента, предположительно, были предварительно нагреты за счет интрудирования ранними дайками (?) и подвергнуты частичному плавлению, как свидетельствует присутствие кварц-полевошпатовых пегматитовых жил. Помимо этого, в при частичном плавлении произошла мобилизация летучих компонентов и, как следствие, локальное обогащение магмы водой и другими флюидами. Это имело двоякий эффект: 1) произошло понижение температуры плавления магмы, которое обусловило частичное плавление кумулусных фаз в кристаллической каше; 2) понизилась вязкость интерстициальной жидкости. Таким образом, с одной стороны, это привело к увеличению пористости кристаллической каши в области нижнего контакта, позволяя сульфидам накапливаться вблизи основания массива. С другой стороны, локальное понижение вязкости магмы облегчило гравитационной осаждение сульфидных капель. Местами, осаждение сульфидной жидкости затронуло породы фундамента, о чем свидетельствует минерализованные диориты (рис. 2). Проникновение сульфидов в поро- 

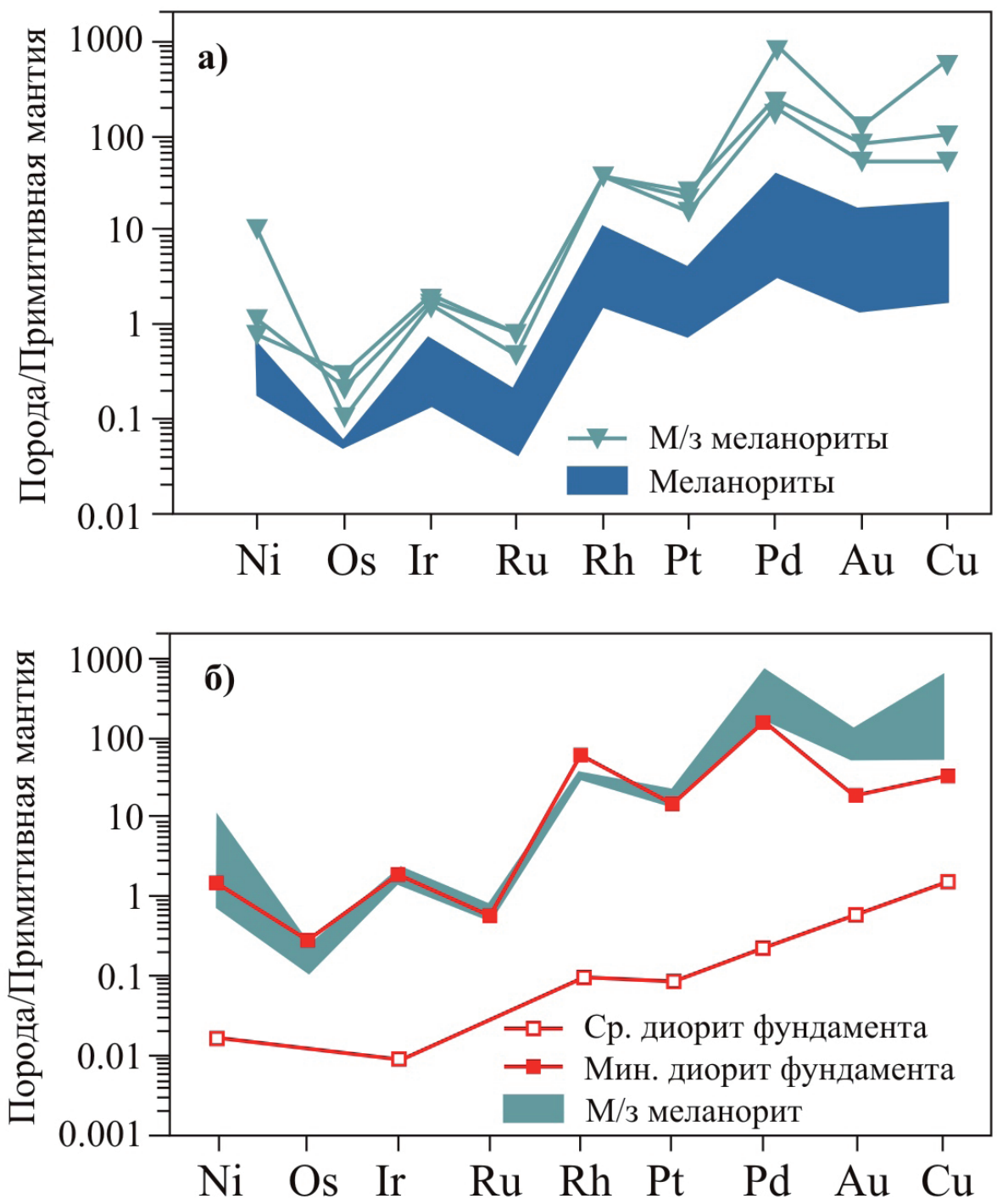

Рис. 3. Нормированные к примитивной мантии [2] спектры халькофильных элементов в породах массива Нюд и диоритах фундамента.

ды рамы наблюдалось также в комплексе Портимо в Финляндии [5], где контактовое оруденение тянется на десятки метров в вглубь фундамента.

Оценка состава родоначальной магмы довольно проблематична для Мончеплутона в связи с отсутствием зон закалки. Близким по составу к такой магме, на наш взгляд, могут выступать палеопротерозойские пикриты Северной Финляндии [4] со средней магнезиальностью (Mg\#) 66.7 мол. \%. Принимая за исходную магму пикрит с 498 ppm Ni, 86 ppm Cu, 9.54 ppb Pd и 0.76 ppb Ir из работы [1], полученные геохимические данные по базальному платинометальному оруденению Нюда могут быть объяснены сегрегацией сульфидов при значениях R-фактора от 2000 до 4000 при ограниченном фракционировании сульфидной жидкости (рис. 4). Из диаграммы на рис. 4 видно, что моносульфидный твердый раствор (mss) недостаточно представлен в полученном наборе данных. Вероятно, это указывает на наличие обогащенных mss сульфидов на более глубоких уровнях.

Исследования выполнены в рамках темы НИР ГИ КНЦ РАН № 0231-2015-0002. 


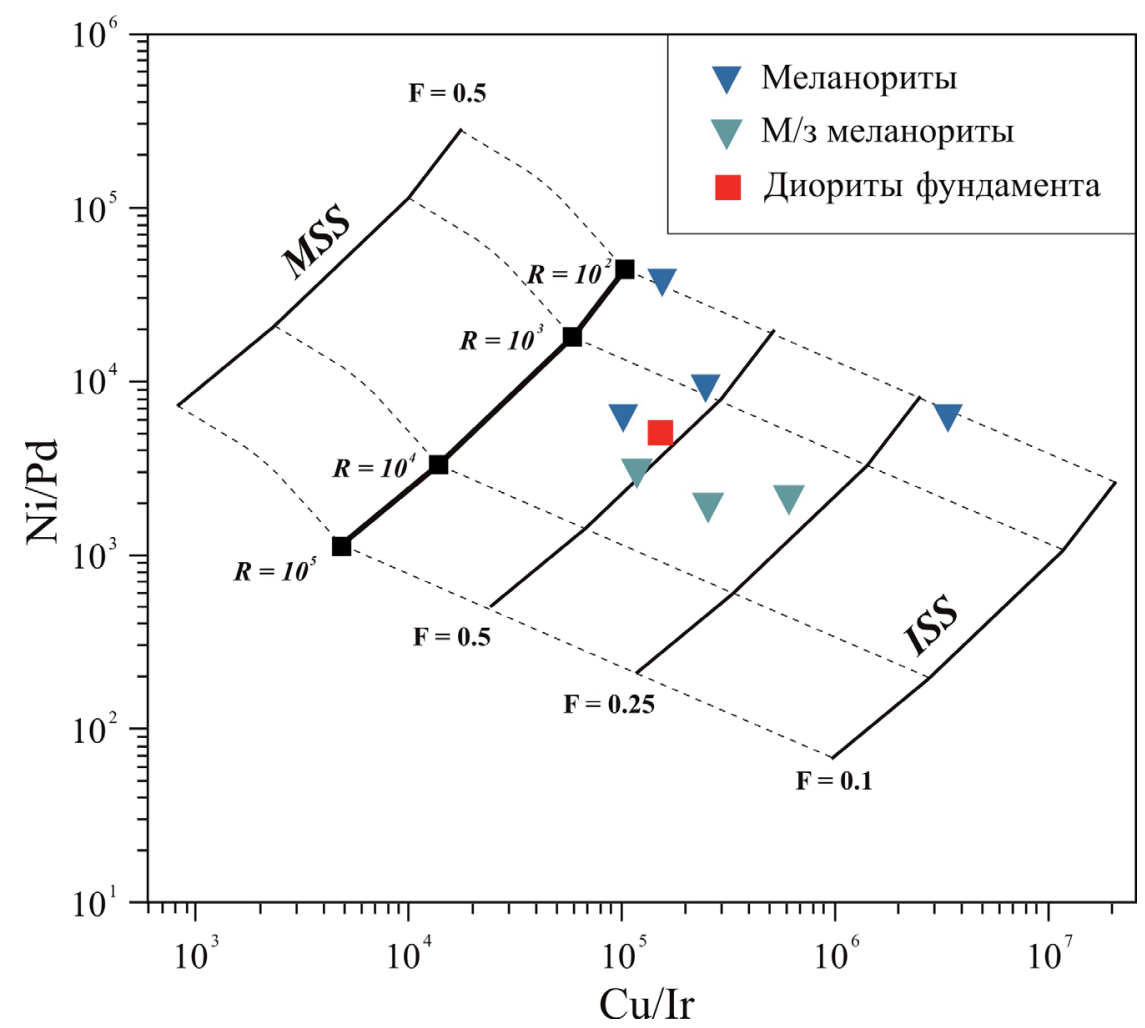

Рис. 4. Диаграмма бинарных отношений Ni/Pd и $\mathrm{Cu} / \mathrm{Ir}$.

Пунктирные линии отражают составы смесей моносульфидного (mss) и переходного (iss) твердых растворов, кристаллизующихся из фракционирующих сульфидных жидкостей. Сплошные линии показывают разные конечные члены составов mss и iss c разной степенью фракционирования (F - доля остаточного распла-

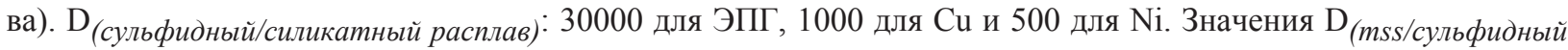
расплав) приведены в [2].

\section{Литература}

1. Barnes S.J., Lightfoot P.C. Formation of magmatic nickel sulfide ore deposits and processes affecting their copper and platinum group element contents // Economic geology $100^{\text {th }}$ anniversary volume. 2005. V. 34. P. 179-214.

2. Barnes S.-J., Maier W.D. The fractionation of $\mathrm{Ni}, \mathrm{Cu}$ and the noble metals in silicate and sulfide liquids / Dynamic Processes in Magmatic Ore Deposits and Their Application in Mineral Exploration, Geological Association of Canada, Short Course. 1999. V. 13. P. 69-106.

3. Bekker A., Grokhovskaya T.L., Hiebert R., Sharkov E.V., Bui T.H., Stadnek K.R., Chashchin V.V., Wing B.A. Multiple sulfur isotope and mineralogical constraints on the genesis of Ni-Cu-PGE magmatic sulfide mineralization of the Monchegorsk Igneous Complex, Kola Peninsula, Russia // Miner. Deposita. 2016. V. 51. I. 8. P. 1035-1053.

4. Hanski E., Huhma H., Rastas P., Kamenetsky V.S. The Palaeoproterozoic Komatiite-Picrite Association of Finnish Lapland // J. Petrol. 2001. V. 42. P. 855-876.

5. Iljina M.J., Alapieti T.T., McElduff B.M. Platinum-group element mineralization in the Suhanko-Konttijärvi intrusion, Finland // Australian Journal of Earth Sciences. 1992. V. 39. I. 3. P. 303-313.

6. Li C., Naldrett A.J. Sulfide capacity of magma; a quantitative model and its application to the formation of sulfide ores at Sudbury, Ontario // Economic Geology. 1993. V. 88. I. 5. P. 1253-1260.

7. Savard D., Barnes S.J., Meisel T. Comparison between Nickel-Sulfur Fire Assay Te Co-precipitation and Isotope Dilution with High-Pressure Asher Acid Digestion for the Determination of Platinum-Group Elements, Rhenium and Gold // Geostandards and Geoanalytical Research. 2010. V. 34. I. 3. P. 281-291. 